\title{
Calli Ultrastructure of Globularia trichosantha ssp. trichosantha
}

\author{
HAVVA ATAR ${ }^{1}$ \\ HATICE CÖLGECEN ${ }^{1}$ \\ GENÇAY AKGÜL² \\ ${ }^{1}$ Department of Biology, Bülent Ecevit University, \\ 67100 Zonguldak, Turkey \\ ${ }^{2}$ Department of Biology, Nevşehir University, \\ 50000 Nevşehir, Turkey

\section{Correspondence:} \\ Havva Atar \\ havva01030@hotmail.com \\ Abbreviations \\ BAP - Benzyl Amino Purine \\ IAA - Indole Acetic Acid \\ MS - Murashige and Skoog \\ $\mathrm{Na}$ - Sodium \\ NAA - Naphthalene Acetic Acid \\ $\mathrm{Pb}$ - Lead \\ TEM - Transmission Electron Microscope \\ UA - Uranyl Acetate \\ 2,4-D - 2,4-Dichlorophenoxy Acetic Acid
}

Key words: Globularia trichosantha ssp. trichosantha, callus, ultrastructure.

Received September 12, 2016

Revised September 15, 2017.

Accepted September 28, 2017.

\section{Abstract}

Background and Purpose: This study aimed to produce calli with explants of aseptic seedlings after germination of $\mathrm{G}$. trichosantha ssp. trichosantha seeds by plant tissue culture method and to examine the ultrastructure of the produced calli with electron microscope preparation.

Materials and Methods: Seeds of G. trichosantha ssp. trichosantha were germinated in hormone-free Murashige and Skoog in in vitro conditions. Hypocotyl, epicotyl, cotyledon, young primer leaf, apical meristem and root explants taken from 30-day aseptic seedlings were transferred to $\mathrm{Mu}$ rashige and Skoog media for callus production which contained varying concentrations of 6-benzilamynopurine, indole acetic acid and 2,4 dichlorophenoxyacetic acid.

Results: Two types of calli were determined: Yellow calli (Type 1) and Black calli (Type 2) with darkened colour and appearance that have not lost their development properties. Following lead staining, thin sections were examined by transmission electron microscope. The best callus production occurred at the Murashige and Skoog medium containing indole acetic acid and 6-benzilamynopurine and in root explants. The cells of Type 1 calli were spherical and large. The cells contained usually one nucleus and nucleolus. Also the cells contained a very large vacuole, endoplasmic reticulum, golgi complex, mitochondria, ribosomes, plastids. Deformed cells and spherical cells were determined in Type 2 calli. The cells were observed to have smaller vacoules and higher numbers of mitochondria different from Type 1 calli. Type 1 and Type 2 calli showed bulging mitochondrial cristae. Electrondense droplets were observed in vacuoles of both Type 1 and Type 2 calli.

\section{INTRODUCTION}

Clobularia (Plantaginaceae) is represented by 22 species worldwide.

Tsome Globularia species are ornamental. The members of the genus Globularia are distributed mainly in Mediterranean Phytogeographical Region and also in Iran Turan and Europe Siberia Phytogeographical Regions (1). Globularia species have medical and economic importance and are also planted as ornamental plants in parks and gardens for their good-looking appearance. They are used for treatment of hemorrhoid and they have diuretic, purgative, stomachic and supporting properties. Globularia species are reported to decrease blood glucose levels $(2,3,4)$, decrease serotonin and histamin secretion (5) and be used as hypoglycemic, purgative, diuretic, stomachic and supporting, cholagogic, headache inhibiting and sudorific agents $(6,7)$. Additionally, they are known to decrease hypertriglyceridemia and improve oxidation in heart, kidney and muscles of rats fed on a high fructose diet (8). They 
are utilized as ingredients in the formulation of strong tonic, sedative, anti-inflammatory, anti-rheumatic, antiulcer, hypo and hypertension medicine. They are reported to stimulate bile secretion from liver, narrow blood vessels and to have heptaprotective, anti-inflammatory, anti-viral and anti-bacterial effects (9).

No plant tissue study has been conducted for species $G$. trichosantha ssp. trichosantha and there are only a few plant tissue culture studies for members of the genus. For G. alypum L., seeds were germinated on hormone-free Murashige and Skoog (MS) medium and plant regeneration was performed using varying doses of naphthalene acetic acid (NAA) and benzyl amino purine (BAP) concentrations (10).

No electron microscope study has been conducted for species G. trichosantha ssp. trichosantha and for other members of the genus. Researchers have conducted ultrastructural analyses on calli of some plants such as Panicum maximum, Pinus nigra, Allium sativum, banana and palm $(11,12,13,14,15)$.

This is the first study which aimed to experiment plant growth regulators on cultured G. trichosantha ssp. trichosantha plant, produce calli in MS media (indole acetic acid (IAA)+BAP and 2,4- dichlorophenoxyacetic acid $(2,4-D)+B A P)$, perform ultrastructural analysis of the calli by transmission electron microscope (TEM). It was aimed to identify the differences between yellow callus and black callus structures which were produced in vitro.

\section{MATERIALS AND METHODS}

Plant materials, trials and culture medium. G. trichosantha ssp. trichosantha seeds were supplied from herbarium samples of Assist. Dr. Gencay AKGÜL from Nevşehir University, Faculty of Arts and Science, Department of Biology. For in vitro germination of $G$. trichosantha ssp. trichosantha seeds, seeds were treated with $10 \%$ sodium hypochlorite solution for 10 min.s. After rinsing with sterilized distilled water, they were kept at 70\% alcohol for $1 \mathrm{~min}$. Seeds were rewashed with sterilized distilled water and treated with $10 \%$ hydrogen peroxide. Lastly, seeds were washed three times with sterilized distilled water.
Sterile seeds were germinated on half-strength hormone-free semi-solid MS (16) medium containing 8\% agar and 3\% sucrose. No plant growth regulators (PGRs) were added. The medium was adjusted to $\mathrm{pH} 5.9$ before autoclaving $\left(20 \mathrm{~min}\right.$ at $\left.121^{\circ} \mathrm{C}\right)$. Seeds were germinated in jars $(7 \times 5 \times 5 \mathrm{~cm})$ (Fig. 1a). Root $(0.5 \mathrm{~cm})$, hypocotyl $(0.5$ $\mathrm{cm})$, apical meristem $(1 \mathrm{~mm})$, cotyledon (splitted in half), epicotyl $(0.5 \mathrm{~cm})$ and young primer leaf (splitted in half) explants were taken from 30 day aseptic seedlings. These explants were transferred to MS medium for callus production which contained varying concentrations and combinations of PGRs (2,4-D+BAP and IAA+BAP) (Table 1).

Plantlets were cultured $16 / 8 \mathrm{~h}$ photoperiod (irradiance of $42 \mu \mathrm{mol} \mathrm{m}{ }^{-2} \mathrm{~s}^{-1}$ provided by cool-white fluorescent tubes) at $25 \pm 2^{\circ} \mathrm{C}$ and subcultured every three weeks for propagation.

Electron microscope preparation. Yellow calli (Type 1) obtained from IAA+BAP containing media and black calli (Type 2) obtained from 2,4-D+BAP containing media were subjected to electron microscope preparation.

Samples were firstly fixed in 3\% glutaraldehyde buffered with $0.1 \mathrm{M}$ phosphate ( $\mathrm{pH} 7.2$ ) for $2 \mathrm{~h}$ at room temperature and then post-fixed with $1 \%$ osmium tetraoxide in $0.1 \mathrm{M}$ phosphate buffer at room temperature for $2 \mathrm{~h}$. Samples were dehydrated with gradual ethanol series followed by propylene oxide and embedded in Epon 812 . Ultrathin sections were stained with $0.5 \%$ uranyl acetate (UA), lead citrate and SATO $((\mathrm{Pb}$ citrate $(0.2 \mathrm{~g})+\mathrm{Pb}$ nitrate $(0.15 \mathrm{~g})+\mathrm{Pb}$ acetate $(0.15 \mathrm{~g})+\mathrm{Na}$ citrate $(1 \mathrm{~g}))$ and examined with EM. Yellow calli obtained from IAA+BAP containing media were stained with SATO and black calli obtained from 2,4-D+BAP containing media were stained with lead citrate. Samples are examined in TEM that is Jeol- JEM- 1220 model and their micrographs are taken.

Statistical analysis. Explants taken from aseptic seedlings and 5 explants were germinated in each petri dish. Germination was completed through three iterative rounds. The proportion of explants in each petri dish forming callus to the explants not forming callus was calculated and callus formation percentage was obtained. The data in percentages were subjected to arcsine trans-
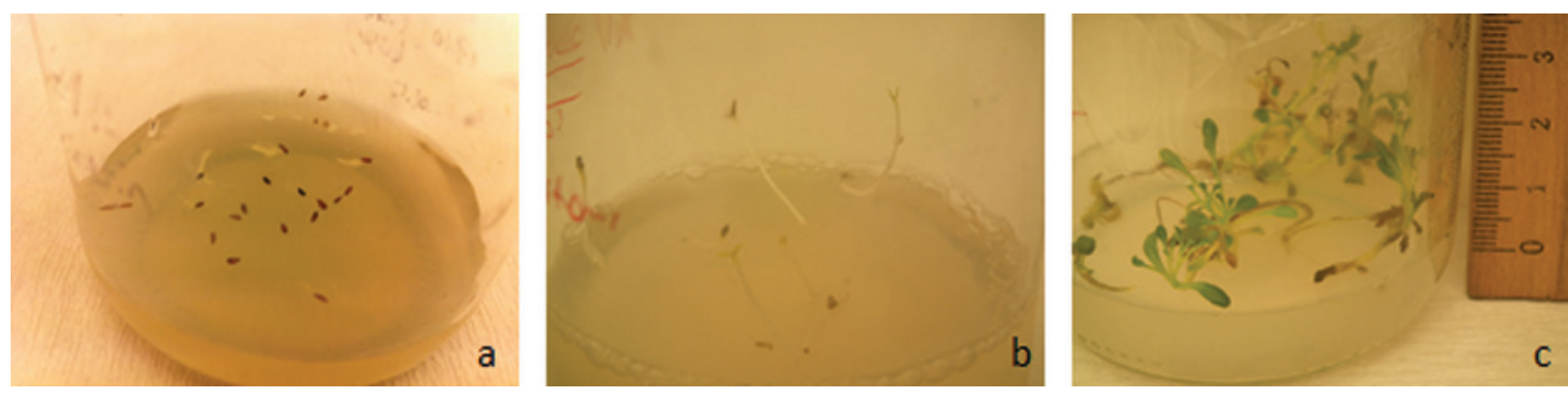

Figure 1. Germination of G.trichosantha ssp. trichosantha in MS medium. (a) Third day of plantation, (b) 15-day seedling, (c) 30-day seedling. 
Table 1. Hormone concentrations used in MS medium

\begin{tabular}{|cccc|}
\hline & IAA+BAP $(\mathrm{mg} / \mathrm{lt})$ & & 2,4-D+BAP $(\mathrm{mg} / \mathrm{lt})$ \\
\hline MS1 & $4-1$ & MS5 & $0.2-0.02$ \\
MS2 & $4-2$ & MS6 & $0.2-0.1$ \\
MS3 & $4-3$ & MS7 & $0.2-0.15$ \\
MS4 & $4-5$ & MS8 & $0.2-0.2$ \\
\hline
\end{tabular}

Table 2. Effect of aseptic seedling age on callus formation percentage

\begin{tabular}{|lcc|}
\hline IAA+BAP (MS3) & 30-day seedlings & 45-day seedlings \\
\hline Hypocotyl & $\mathbf{8 3 . 2 3} \pm \mathbf{1 . 4 8}$ & $60.00 \pm 0.18$ \\
Cotyledon & $\mathbf{8 4 . 2 6} \pm \mathbf{0 . 1 7}$ & $59.00 \pm 0.18$ \\
Young primer leaf & $26.39 \pm 0.44$ & $\mathbf{8 4 . 5 6} \pm 0.17$ \\
Epicotyl & $35.05 \pm 0.35$ & $\mathbf{8 5 . 2 6} \pm 0.17$ \\
Apical Meristem & $\mathbf{8 5 . 7 6} \pm \mathbf{0 . 1 7}$ & $63.77 \pm 0.20$ \\
Root & $\mathbf{8 6 . 1 6} \pm \mathbf{0 . 1 7}$ & $83.66 \pm 0.17$ \\
\hline
\end{tabular}

Mean \pm SE

formation (17) before statistical analysis. Callus growth index was calculated as given below (18):

„SPSS for Windows Ver. 19.0” (SPSS Inc., Chicago, IL., USA) was used for all statistical analyses and calculations and one way analysis of variance (ANOVA). The differences among means were compared by Duncan's multiple- range test (19). A significance level of $\mathrm{p}<0,05$ was referred as statistically significant.

\section{RESULTS}

The seeds of $G$. trichosantha ssp. trichosantha were germinated in hormone-free MS medium with $80 \%$ success rate. Seeds took up 3 days to germinate. Root was the first portion to emerge followed by hypocotyl and cotyledons (Fig. 1).

Hypocotyl, epicotyl, cotyledon, young primer leaf, apical meristem and root explants taken from 30-day and 45-day aseptic seedlings were transferred to hormone-free MS media containing varying concentrations and combinations of plant growth regulators. The effect of explant age on callus formation percentage was examined. Due to low number of seeds, MS3 medium was used for trial based on our pre-trials. Explants taken from 30-day aseptic seedlings were generally observed to perform better and result higher percentages of callus formation compared to the explants taken from 45-day aseptic seedlings. Lower percentage of callus formation was measured in young primer leaf and epicotyl explants taken from 30day seedlings compared to those taken from 45-day seedlings (Table 2). Due to higher percentages of callus formation obtained from hypocotyl, cotyledon, apical meristem and root explants from 30-day seedlings, these younger seedlings were decided to be used in the rest of the trials.

For all media, the fastest callus forming explants of plants were root (after 3 days), hypocotyl (after 7 days) and apical meristem (after 7 days). Calli in the media containing IAA+BAP and 2,4-D+BAP were composed of spherical and regular bodies. While calli in the media containing 2,4-D+BAP were mostly black coloured (Type 2) (Fig. 3) they were initially yellow coloured (Type 1) but started to darken after second subculture in media containing IAA+BAP (Fig. 2). Nevertheless, callus formation continued with sustained cell division. Young, light coloured and spherical calli continued to grow besides darkened calli in the media containing IAA+BAP (Fig. 2).

According to the results of callus formation percentages, in the media containing IAA+BAP, hypocotyl, young primer leaf and epicotyl explants proved to be successful in MS3 medium, cotyledon and apical meristem explants proved to be successful in MS4 medium and root explants proved to be successful in MS2 medium (Table 3).

In the media containing 2,4-D+BAP, hypocotyl and root explants proved to be successful in MS1 medium, cotyledon and young primer leaf explants proved to be successful in MS3 medium and epicotyl and apical meristem explants proved to be successful in MS4 medium (Table 3).

The highest callus formation percentages of all explants were measured in the media containing IAA+BAP
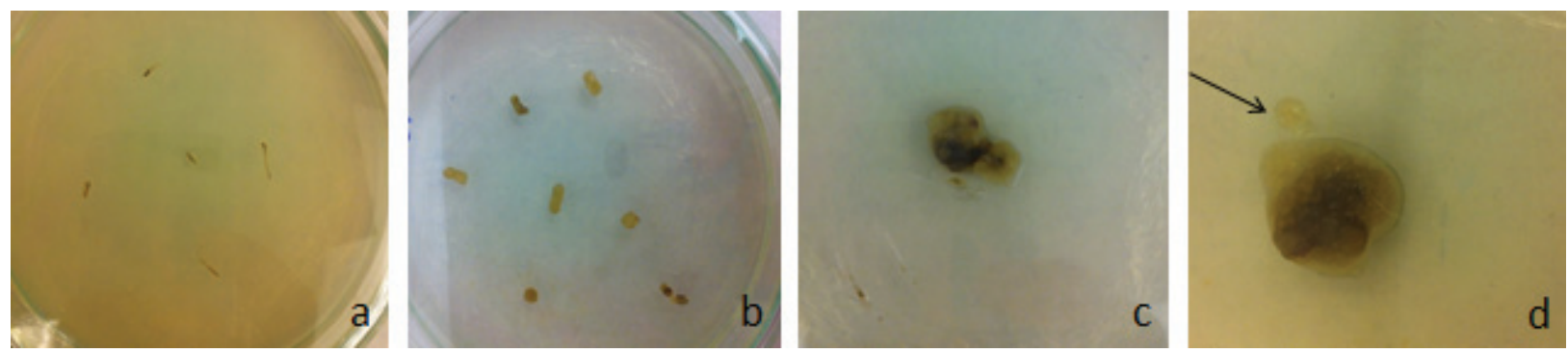

Figure 2. Appearance of $\mathrm{G}$. trichosantha ssp. trichosantha calli in the media containing IAA+BAP (MS3). (a) root explants (b) initial callus formation after 2 weeks (c) appearance of calli after 6 weeks (d) appearance of calli after 9 weeks. 
Table 3. The effect of plant growth regulators on callus formation percentage of each explant of $\mathrm{G}$. trichosantha ssp. trichosantha in the first subculture

\begin{tabular}{|c|c|c|c|c|c|c|}
\hline Media & Hypocotyl & Cotyledon & Young Primer Leaf & Epicotyl & Apical Meristem & Root \\
\hline \multicolumn{7}{|c|}{$\mathrm{IAA}+\mathrm{BAP}$} \\
\hline MS1 & $21.76 \pm 0.47^{d}$ & $63.77 \pm 0.20^{b}$ & $43.10 \pm 0.40^{b}$ & $45.10 \pm 0.41^{\mathrm{c}}$ & $21.99 \pm 0.37^{\mathrm{d}}$ & $81.56 \pm 0.90^{b}$ \\
\hline MS2 & $45.10 \pm 0.41^{c}$ & $50.75 \pm 0.35^{\mathrm{c}}$ & $26.50 \pm 0.62^{d}$ & $35.24 \pm 0.34^{\mathrm{d}}$ & $53.69 \pm 0.34^{b}$ & $83.56 \pm 1.01^{\mathrm{a}}$ \\
\hline MS3 & $83.56 \pm 1.01^{\mathrm{a}}$ & $45.10 \pm 0.41^{\mathrm{d}}$ & $45.10 \pm 0.41^{\mathrm{a}}$ & $63.77 \pm 0.20^{\mathrm{a}}$ & $29.99 \pm 0.38^{c}$ & $70.46 \pm 0.52^{c}$ \\
\hline MS4 & $63.77 \pm 0.20^{\mathrm{b}}$ & $83.56 \pm 1.01^{a}$ & $35.24 \pm 0.34^{c}$ & $50.75 \pm 0.35^{b}$ & $54.69 \pm 0.34^{\mathrm{a}}$ & $52.23 \pm 0.34^{\mathrm{d}}$ \\
\hline \multicolumn{7}{|c|}{ 2,4-D+ BAP } \\
\hline MS1 & $84.56 \pm 0.17^{\mathrm{a}}$ & $19.27 \pm 0.45^{b}$ & $10.27 \pm 0.50^{\mathrm{d}}$ & $83.56 \pm 0.15^{\mathrm{b}}$ & $82.56 \pm 0.15^{b}$ & $84.56 \pm 0.17^{\mathrm{a}}$ \\
\hline MS2 & $45.10 \pm 0.41^{\mathrm{b}}$ & $10.27 \pm 0.50^{\mathrm{d}}$ & $35.07 \pm 0.35^{\mathrm{c}}$ & $35.07 \pm 0.35^{\mathrm{b}}$ & $45.10 \pm 0.41^{\mathrm{c}}$ & $45.10 \pm 0.41^{\mathrm{c}}$ \\
\hline MS3 & $33.27 \pm 0.47^{d}$ & $21.96 \pm 0.47^{\mathrm{a}}$ & $84.56 \pm 0.17^{\mathrm{a}}$ & $26.79 \pm 0.62^{c}$ & $33.27 \pm 0.47^{d}$ & $26.79 \pm 0.62^{\mathrm{d}}$ \\
\hline MS4 & $83.56 \pm 0.17^{b}$ & $12.27 \pm 0.89^{c}$ & $45.10 \pm 0.41^{\mathrm{b}}$ & $84.56 \pm 0.17^{\mathrm{a}}$ & $84.56 \pm 0.17^{\mathrm{a}}$ & $63.77 \pm 0.20^{\mathrm{b}}$ \\
\hline
\end{tabular}

Mean \pm SE

Table 4. Plant growth regulators, total callus formation percentages of all explants and callus growth indexes in in vitro culture of $\mathrm{G}$. trichosantha ssp. trichosantha

\begin{tabular}{|c|c|c|c|c|}
\hline Media & $\begin{array}{l}\text { Hormone concentrations } \\
\qquad(\mathrm{mg} / \mathrm{lt})\end{array}$ & $\begin{array}{l}\text { Callus formation } \\
\text { percentage }\end{array}$ & $\begin{array}{l}\text { Callus growth index } \\
\text { (First Subculture) }\end{array}$ & $\begin{array}{l}\text { Callus growth index } \\
\text { (Second Subculture) }\end{array}$ \\
\hline \multicolumn{5}{|c|}{$\mathrm{IAA+BAP}$} \\
\hline MS1 & 2 & $42.75 \pm 0.64^{c}$ & 0.95 & 0.82 \\
\hline MS2 & 4 & $52.23 \pm 0.34^{\mathbf{b}}$ & 0.94 & 1.52 \\
\hline MS3 & 6 & $66.39 \pm 0.56^{a}$ & 0.98 & 2.16 \\
\hline MS4 & 8 & $52.06 \pm 0.34^{\mathbf{b}}$ & 0.98 & 1.39 \\
\hline \multicolumn{5}{|c|}{ 2,4-D+BAP } \\
\hline MS5 & $0.2-0.02$ & $54.69 \pm 0.34^{b}$ & 0.63 & 10.80 \\
\hline MS6 & $0.2-0.1$ & $37.11 \pm 0.20^{c}$ & 0.76 & 27.17 \\
\hline MS7 & $0.2-0.15$ & $28.11 \pm 0.16^{d}$ & 0.46 & 10.38 \\
\hline MS8 & $0.2-0.2$ & $56.02 \pm 2.99^{\mathrm{a}}$ & 0.78 & 13.04 \\
\hline
\end{tabular}

Mean \pm SE

compared to those containing 2,4-D+BAP (Table 4). MS3 proved to be the most successful medium of those containing IAA+BAP while MS8 was the most successful of those containing 2,4-D+BAP.
In the first subculture, with respect to callus growth index, MS3 and MS4 proved to be the most successful of the media containing IAA+BAP while MS8 was the most successful of those containing 2,4-D+BAP. In the second
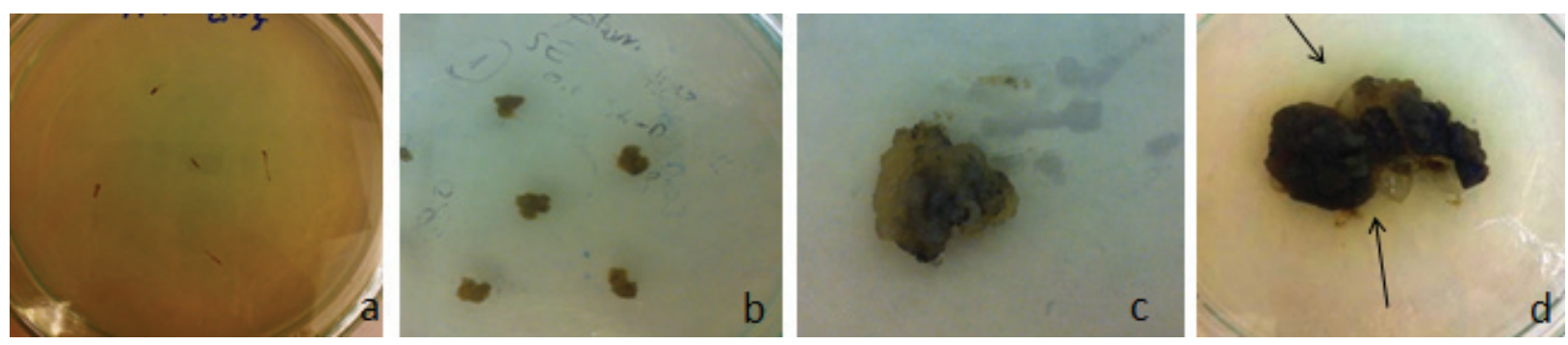

Figure 3. Appearance of $\mathrm{G}$. trichosantha ssp. trichosantha calli in the media containing 2,4-D+BAP (MS8). (a) root explants (b) initial callus formation after 2 weeks (c) appearance of calli after 6 weeks (d) appearance of calli after 9 weeks. 
subculture, MS8 resulted the highest callus growth index among the media containing IAA+BAP and MS6 resulted the highest callus growth index among the media containing 2,4-D+BAP (Table 4).

Ultrastructure of type 1 (yellow) callus cells. Large spherical parenchymatic callus cells were observed in Type 1 calli (Fig. 4a-f). These cells generally have only one nucle-
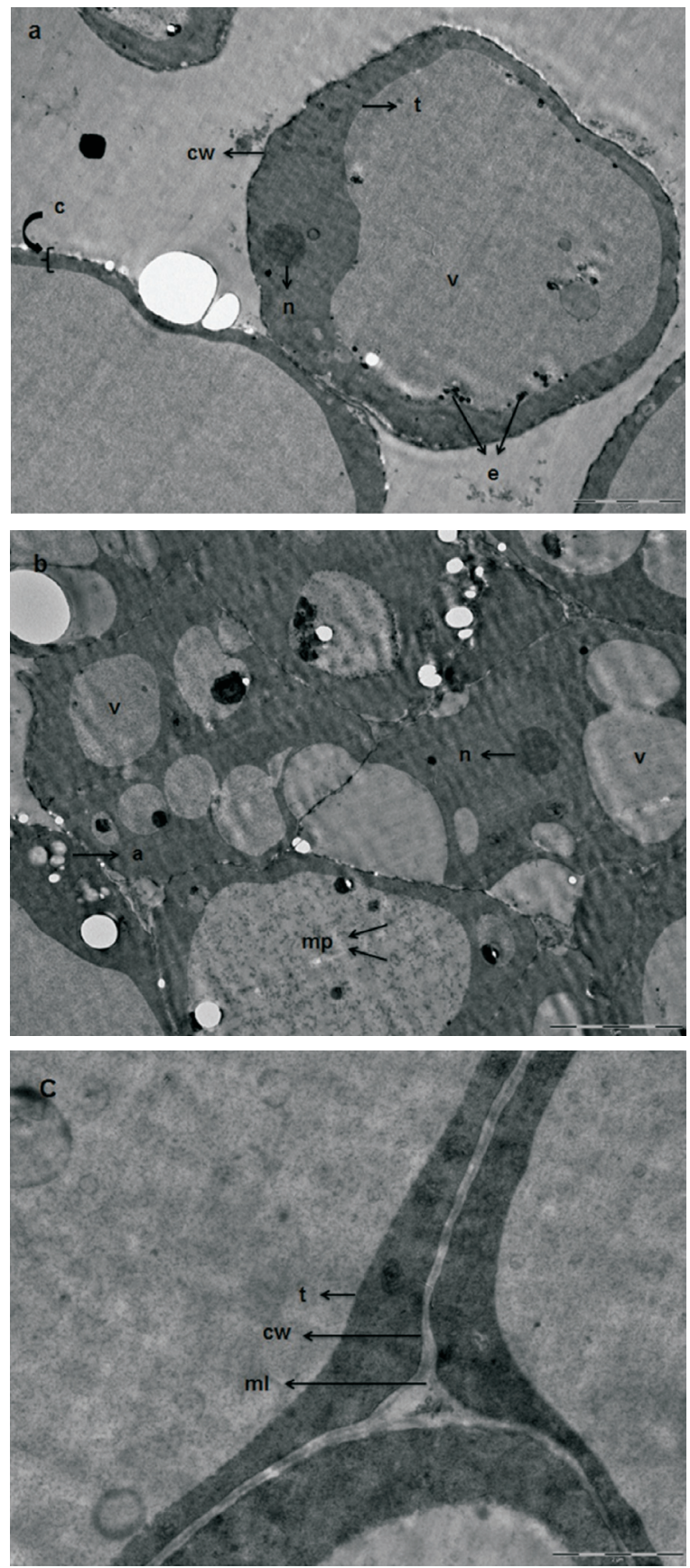

us with a nucleolus (Fig. 4b). Nucleolar vacuoles when they are small are located in the centre and gradually pushed towards the wall as they enlarge. Plasma membrane is smooth (Fig. 4c). Middle lamella is clearly seen and the boundaries between adjacent cells are visible (Fig. 4c). There are various accumulations in intercellular spaces. There is granular endoplasmic reticulum without layers close to cell membrane (Fig. $4 \mathrm{~d}$ ).
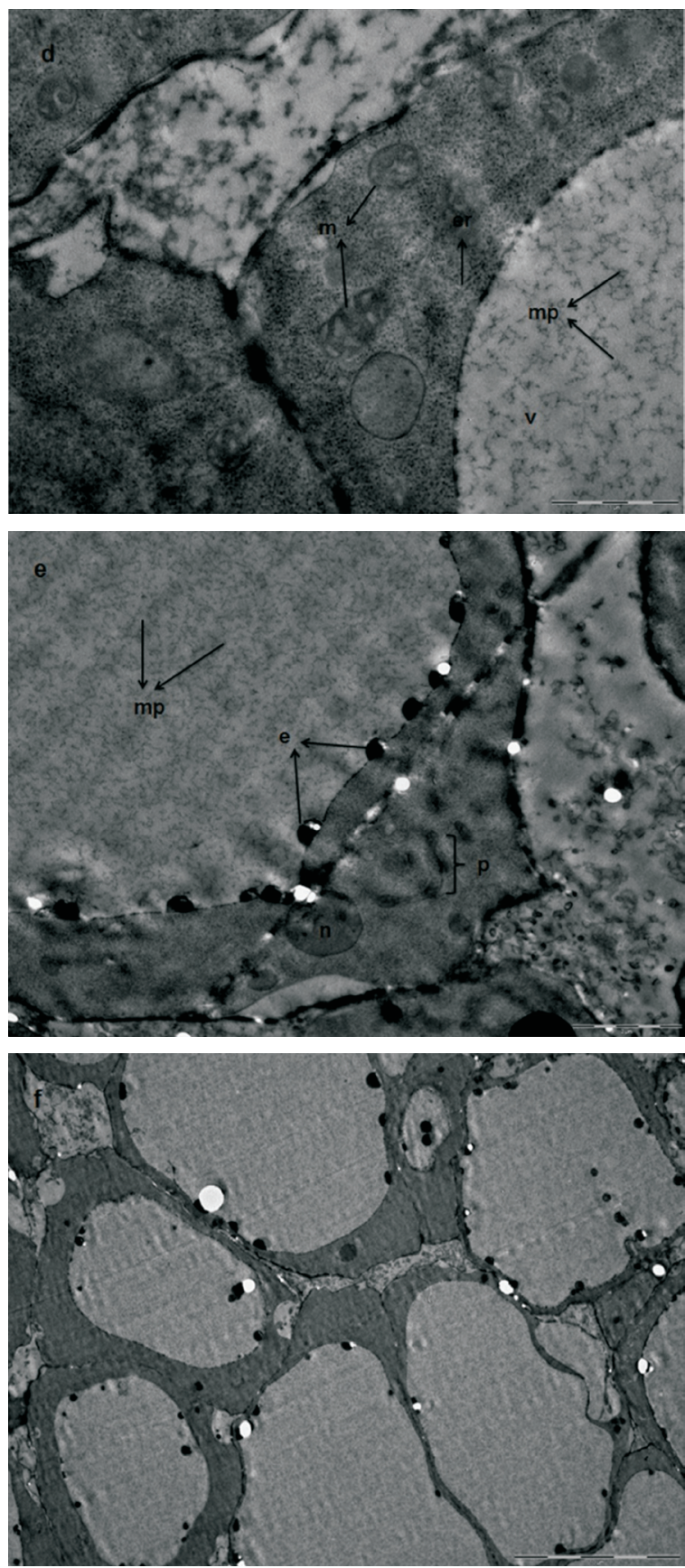

Figure 4. Ultrastructure of yellow calli obtained from media containing IAA+BAP. (a) spherical cells, bar=5um (b) nucleus and vacu-

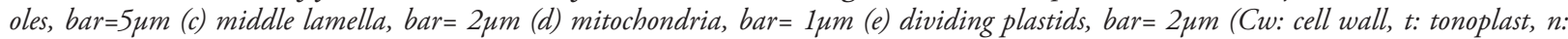
nucleus, v: vacuole, e: electron-dense droplets, c: cytoplasma, a: amyloplast, mp: membrane particles, ml: middle layer, m: mitochondria, er: endoplazmic reticulum, $p$ : plastid). 

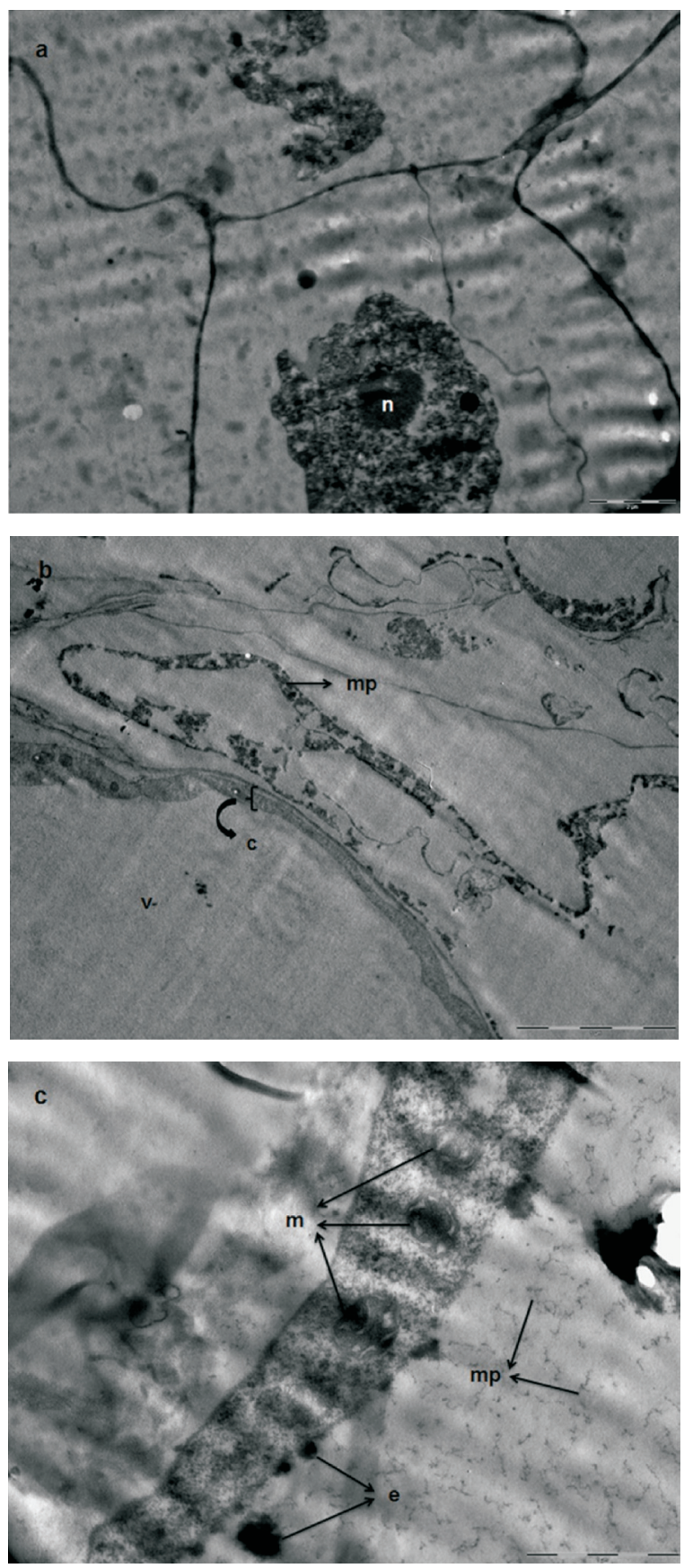

The cells of Type 1 calli have large vacuoles. In vacuoles, there are generally electron-dense droplets attached to tonoplast (Fig. 4a) and membrane pieces (Fig. 4b). Due to accumulation of high amount of water in vacuoles, cytoplasm is squeezed between the cell wall and tonoplast (Fig. 4c). These numerous small vacuoles expand and merge as the cell matures. There are proplastids of different sizes. As the vacuoles grow, starch is stored in cells and proplastids are converted to amyloplasts (Fig. 4b). Each callus cell has a number of amyloplasts that contain starch grains.
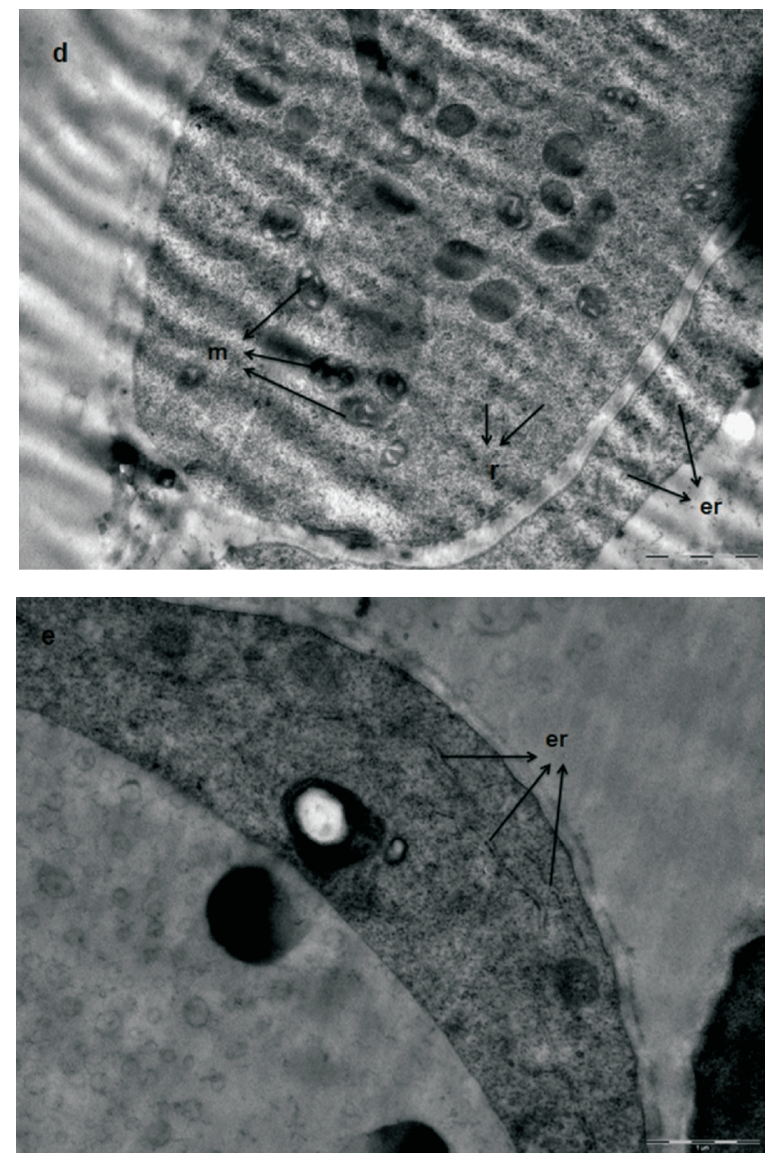

Figure 5. Ultrastructure of black calli obtained from media containing 2,4-D+BAP. (a) spherical cells, bar $=2 \mu m$ (b) plasma membrane, bar $=5 \mu \mathrm{m}$ (c) mitochondria, bar $=1 \mu \mathrm{m}$ (d) ribosomes and endoplasmic reticulum, bar $=1 \mu m$ (n: nucleus, e: electrondense droplets, c: cytoplasm mp: membrane particles, m: mitochondria, r: ribozomes, er: endoplazmic reticulum).

The cytoplasm has large numbers of spherical mitochondria in Type 1 callus cells (Fig. 4d). All mitochondria have bulging cristae. Dividing mitochondria are seen. There are large numbers of ribosomes in the cytoplasm. Diving plastids are observed (Fig. 4e).

Ultrastructure of type 2 (black) callus cells. In Type 2 calli, there are large, spherical and also elongated, irregular shaped cells (Fig. 5a-b). There is generally only one nucleus like in Type 1 calli and nucleous generally contains only one nucleolus. Nuclear envelope has a wavy appearance. Cell boundaries are visible in some cells and 
not visible in others. Nuclear membrane partly extends inward (Fig. 5a). Endoplazmic reticulums have surrounded nucleus (Fig. 5e). Type 2 calli have smaller and higher number of vacuoles. There is a large amount of mitochondria. Mitochondria are mostly spherical with some eliptical shaped. All mitochondria have bulging cristae (Fig. $5 \mathrm{~d})$. Electron-dense droplets are seen in vacuoles. There are large numbers of ribosomes in the cytoplasm (Fig. 5c).

The measurements on nuclear diameters indicated that Type 1 calli had an average nuclear diameter of $7,12 \mu \mathrm{m}$ (scale bar $=10 \mu \mathrm{m}$ ) and Type 2 calli had an average nuclear diameter of $9,61 \mu \mathrm{m}$ (scale bar=10 $\mu \mathrm{m})$.

\section{DISCUSSION}

The seeds of $G$. trichosantha ssp. trichosantha were germinated in hormone-free MS medium with $80 \%$ success rate. Explants taken from 30-day aseptic seedlings were transferred to MS media supplemented with plant growth regulators for callus production.

Mainly genotypical variation and other various factors such as the organs used as explant sources and their ontogenic and physiological age may affect the behaviour of cultured explants (20). Callus production proved to be succesful in all hypocotyl, cotyledon, young primer leaf, epicotyl, apical meristem and root explants. However, root was the most successful of all explants with the fastest callus formation (after 3 days). Delayed callus formation was observed in other explants. The explants taken from 30-day and 45-day seedlings were transferred to MS3 media containing IAA+BAP as determined during our pre-trials, and the effect of explant age on callus formation percentage was examined. Explants taken from 30-day aseptic seedlings generally resulted faster (with 3-day intervals) and higher callus formation compared to the explants taken from 45-day aseptic seedlings (Table 2). Bertsouklis et al., (2003) reported that 60-day aseptic seedlings obtained from species $G$. alypum L. proved to be successful in callus formation (10). Nevertheless, in our study, 60-day aseptic seedlings of $G$. trichosantha ssp. trichosantha went pale and moreover, fading was observed in the cotyledons of 45-day seedlings. Hence, 30-day aseptic seedlings were found to be more appropriate. Since it was possible to obtain adequate amount of calli from the explants of 30-day aseptic seedlings, these seedlings were used in the rest of the trials.

Callus culture was performed successfully. In the media containing IAA+BAP, calli were initially yellow-coloured and then darkened after second subculture. In the media containing 2,4-D+BAP, callus darkening occurred within the first week and was maintained throughout growth. Nevertheless, no necrosis was noted in the cultures and new callus formation was observed besides the black coloured calli. Hence, callus culture maintained continuity which enabled calculation of callus formation percentage and callus growth index (Table 3, Table 4).
As indicated by callus formation percentages, MS3 media containing IAA+BAP proved to be more successful for callus formation compared to media containing 2,4-D+BAP (Table 4). On the other hand, the results of callus growth indexes revealed that media containing 2,4-D+BAP was more successful for callus growth compared to the media containing IAA+BAP. MS8 was the most successful of 2,4-D+BAP containing media. Callus formation increased by almost 10-27 times in the second subculture compared to the first in 2,4-D+BAP containing media. Whereas, callus formation increased by almost 1-2 times in the media containing (Table 4). While BAP was effective at low concentrations when used as 2,4-D auxin, BAP induced yellow callus formation at high concentrations when used as IAA auxin but did not have a significant effect on increasing callus amount.

The literature review indicates that there is no tissue culture study on $G$. trichosantha ssp. trichosantha. Bertsouklis et al., (2003) germinated the seeds of G. alypum L. on semi-solid ( $8 \mathrm{~g} \mathrm{~L}^{-1}$ agar) and solid (20 g L $\mathrm{g}^{-1}$ agar) MS media ( $\mathrm{pH}: 5.7$ ). They used varying concentrations of NAA and BAP for plant regeneration. While root formation was achieved in $8 \mathrm{~g} \mathrm{~L}^{-1}$ agar containing media, the shoots were exposed to hyperhydration which was eliminated by increasing the amount of agar. The researchers tested NAA and BAP containing media and achieved callus formation. $8 \mathrm{~g} \mathrm{~L}^{-1}$ agar was used also in our study similar to the study of these researchers, but despite the use of semi-solid MS medium, no hyperhydration was noted in the seedlings in contrary to the findings of these researchers. No hyperhydration was noted in our study performed with different plant growth regulators (IAA+BAP and 2,4-D+BAP) but use of 2,4-D+BAP was found to induce calli darkening. Similarly, different from the study of Bertsouklis et al., (2003), $30 \mathrm{~g} \mathrm{~L}^{-1}$ sucrose, $\mathrm{pH}$ : 5.9 was used in our study. IAA+BAP containing MS3 medium proved to be the most successful medium for callus formation (Table 4). While IAA+BAP containing MS3 and MS4 media were the most successful for callus growth in the first subculture, 2,4-D+BAP containing MS6 medium proved to be the most successful in the second subculture (Table 4).

After callus formation, ultrastructure of the initiated yellow (Type 1) and black (Type 2) calli was examined. Type 1 and Type 2 callus cells are large and contain only one nucleus. Additionally, malformed cells are also noted in Type 2 calli. While nuclei in Type 1 calli are spherical and smooth (Fig. 4a), those of Type 2 are observed to be malformed (Fig. 5a). The measurements on nuclear diameters are had Type 1 and Type 2 calli but it hasn't been any article about nuclear diameters so nuclear measurements are done with simple mean.

It is noteworthy that Type 1 calli have large vacuoles whereas Type 2 calli have smaller and larger numbers of vacuoles. Vacuole is the organelle where various proteins, sugars, $\mathrm{CO}^{2}$ and water are stored. At the same time, it 
regulates turgor of the plant (21). Occurence of large vacuoles in callus cells of different plant species is common $(11,13)$. Also, large numbers of mitochondria with bulging cristae were noted in the cytoplasm in our study. Presence of bulging mitochondrial cristae in callus cells is reported to be common (22). A similar case is noted in the calli produced from $G$. trichosantha ssp. trichosantha.

In their study on Pinus sylvestris L., Laukkanen et al., (2000) observed darkening in the calli after two weeks of callus formation (23). Callus darkening was attributed to oxidation of phenols accumulated in the cell. They identified the black droplets displayed on TEM micrographs to be phenol. Tang et al., (2004) attributed callus darkening to oxidative stress in their culture study (24). In our study, some electron-dense droplets in Type 2 cells were noted to be attached to tonoplast. These droplets could not be identified, but they were thought to be the possible cause of callus darkening. When compared Type 1 and Type 2, it was seen a lot of electron-dense droplets in Type 2 callus. Moreover, while no malformation was recorded in Type 1 calli, contraction and malformation were noted in the cells of Type 2 calli.

Differences were identified between the nuclei of Type 1 and Type 2 calli in our study with respect to both size and appearance. Change in nucleus is attributed to various factors such as senescence or elicitor $(25,26)$. In our study, cell continuity was maintained in Type 2 calli but living cells were noted to develop besides the necrotic cells. Furthermore, no elicitor application was made on the plant or calli. However, phenol oxidation which is considered to be the probable cause of callus darkening might have led to nucleus malformation and enlargement in Type 2 calli or gradual cellular aging might have occurred during the darkening of yellow calli. In Type 1 calli, cytoplasm is squeezed between vacuole and cell wall. Vacuoles were observed to be large. The high number of vacuoles in Type 2 calli is considered as a sign of aging (27).

Wang et al. (1998) examined the change in callus nuclear structure during callus formation in Allium sativum leaves (13). The samples were kept at $1 \% \mathrm{OsO}_{4}$ for 2 hrs and washed with phosphate buffer solution $0.2 \mathrm{M} \mathrm{pH}$ 7.2. Aceton was used for dehydration and then the samples were embedded in epon. A number of different cell types were noted during the growth of calli such as large vacuolated cells, active phase cells, dividing cells and callus cells. Large vacuolated cells had a small nucleus located between vacuole and cell wall. Active phase cells had a nucleus moving from the cell wall to cytoplasm. During cell division, nucleus was located just next to cell wall or at the center of the cell. In callus cells, nucleus is very large, many nuclei are spherical but no envolope formation was noted in some (13). In our study, 3\% GA was used for preliminary fixation and ethanol was used for dehydration. In, Despite being small, the nucleus in large vacuolated cells was squeezed between vacuole and cell wall in Type 1 calli.

Urbanek et al. (2004) produced somatic embryos from cotyledon calli of Cucurbita pepo L. (24). Calli were fixed in $2.5 \%$ GA with phosphate buffer and post-fixed in $1 \%$ $\mathrm{OsO}_{4}$. Aceton was used for dehydration. Ultrastructure of calli was examined by TEM. Large numbers of plastids and mitochondria with bulging cristae were noted in callus cells with large nucleolus. Additionally, a large amount of endoplasmic reticulum was observed around nucleus. In our study, 3\% GA was used as fixative solution and ethanol was used as dehydration solution. In agreement with the findings of these researchers, large numbers of mitochondria with bulging cristae were noted in the cytoplasm in the cells of both calli. On the other hand, fewer plastids and endoplasmic reticulum were noted.

Stein et al. (2010) cultured calli from anther, ovarium, leaf and nodal segments of Inga vera Willd. subsp. affinis and made preparation from these calli (28). Calli were fixed in Karnovsky (2.5\% GA and 2.5\% paraformaldehyde) solution, post-fixed with $1 \% \mathrm{OsO}_{4}$ solution and dehydrated with aceton. Spurr resin was used as embedding material. A large amount of endoplasmic reticulum was noted in cytoplasm. There is one large nucleus and a nucleolus. The large vacuole caused cytoplasm be squeezed between cell membrane and tonoplast (28). In our study, $3 \%$ GA was used as fixative solution and ethanol was used as dehydration solution. Different from the findings of Stein et al., fewer endoplasmic reticulum was observed in cells of both calli. Cytoplasm was rich in mitochondria in agreement with their findings. Type 1 calli had large vacuoles whereas Type 2 calli had smaller and larger numbers of vacuoles.

Ribeiro et al. (2012) made preparation from the calli of banana and examined morphological and ultrastructure of these calli (14). Calli were fixed in Karnovsky (2.5\% GA and 2.5\% paraformaldehyde) solution and post-fixed with $1 \% \mathrm{OsO}_{4}$ solution. They examined the ultrastructural differences among the three types of calli: Type 1 - transparent aquuswatery callus, Type 2 - yellow callus with small clusters, Type 3 -yellow callus with large clusters. SEM analysis showed that Type 1 callus cells were elongated and that Type 2 and Type 3 callus cells were isodiametric. The TEM analysis showed that Type 1 callus cells had thin walls, a large number of small vacuoles and dispersed cytoplasm. Type 2 callus cells showed dense cytoplasm, large vacuoles and large numbers of mitochondria. The Type 3 callus cells had a thick cell wall and intercellular spaces (14). In our study, 3\% GA was used as fixative solution and epon was used as resin. Type 1 (Yellow) callus cells showed a small amount of cytoplasm but very large vacuoles. Both Type 1 and Type 2 callus cells showed a large amount of mitochondria. Cell wall was visible and smooth in Type 1 callus cells and was generally fragmented in Type 2 callus cells. 
The biochemical and ultrastructural alterations associated with callus browning were examined by using TEM and SEM in calli from Dendrobium crumenatum Swarts (29). Calli were fixed in $2.5 \%$ GA with $0.1 \mathrm{M}$ phosphate buffer and post-fixed in 1\% caffeine and 1\% $\mathrm{OsO}_{4}$ solutions. The biochemical study indicated that browning 3-month-old callus had significantly higher total phenolic content than control callus. The histological study demonstrated that the 1-month-old callus of $D$. crumenatum consisted of uniform and tightly arranged parenchymatous cells. A thin cell wall, tonoplast and plasmodesmata were clearly observed. The well-organized organelles, including a nucleus, mitochondria and chloroplasts, were very apparent in the cytoplasm. However, there were no obvious differences between the 2-month-old callus and 1-month-old green callus. Various organelles in 3-month-old callus cells were completely disorganized. Brown cells had minimal cytoplasm, numerous degraded thylakoid-containing plastids and shrunken plasmalemma resulting in detachment of the plasmalemma from the cell wall (29).

\section{CONCLUSION}

G. trichosantha ssp. trichosantha plant was successfully cultured in our study. In vitro germination was accomplished with a success rate of $80 \%$. 30-day aseptic feedlings were determined to be the most appropriate explant sources for in vitro callus production. As indicated by callus formation percentages, IAA+BAP containing MS3 medium proved to be more successful. Callus growth index values revealed that 2,4-D+BAP containing MS6 and MS8 media are appropriate to be used for callus production. Cellular differences were examined between Type 1 (yellow) and Type 2 (black) calli. In both types, living cells were noted to develop besides the necrotic cells. Phenol oxidation, which is considered to be the possible cause of callus darkening, might have been delayed in Type 1 calli and led to cell and nucleus malformation and nucleus enlargement in both types of calli. The high number of vacuoles and bulging mitochondrial cristae in Type 2 callus cells can be considered as a sign of gradual aging process during the darkening from yellow to black. It is aimed to study the secondary metabolytes in $G$. trichosantha ssp. trichosantha plant and derived calli in our forthcoming research in order to determine the amounts of active ingredients produced. This study has provided the basic data on $G$. trichosantha ssp. trichosantha which can be utilized in further biotechnological studies.

Acknowledgements: We extend our thanks to Eskişehir Osmangazi University and to Associate Professor İlknur Da $\breve{g}$ and Tayfun Şengel for their technical assistance with TEM. Also, the research project was supported by Bülent Ecevit University, Science Research Project No: 2014-8490672703.

\section{REFERENCES}

1. DAVİS PH, MİLL RR, TAN K 1988 Flora of Turkey and the East Aegean Islands, vol. 10. Edinburgh: Edinburgh University Press 201.

2. SKİM F, KAAYA A, JAOUHARİ JT, LAZREK HB, JANA M, EL AMRİ H 1999a Hypoglycaemic activity of Globularia alypum leaves in rats. Fitoterapia 70: 382-389.

3. SKIM F, LAZREK HB, KAAYA A, EL AMRİ H, JANA M 1999 b Pharmacological studies of two antidiabetic plants: Globularia alypum and Zygophyllum gaetulum. Therapie 54(6): 711-715.

4. JOUAD H, MAGHRANİ M, EDDOUKS M 2002 Hypoglycaemic effect of Rubus fructicosis L. And Globularia alypum L. in normal and streptozotocin- induced diabetic rats. Journal of Ethnopharmacology 81:351-356.

5. BELLO R, MORENO L, PRİMO Y, ESPLUGUES J 2002 Globularia alypum L. extracts reduced histamine and serotonin contraction in vitro. Phytotherapy Research 16: 389-392.

6. KIRMIZIBEKMEZ H 1999 Globularia trichosantha fisch. ve mey: üzerinde fitokimyasal araştırmalar (Yüksek Lisans Tezi) Hacettepe Üniversitesi Eczacılık Fakültesi.

7. BOUTITII A, BENGUERBA A, KİTOUNİ R, BOUHROUM M, BENAYACHE S, BENAYACHE F 2008 Secondary Metabolites From Globularia alypum. Chemistry of Natural Compounds 44(4): 543-544.

8. DİDA N, KROUF D, BOUCHENAK M 2011 Globularia alypum aqueous extract decreases hypertriglyceridemia and ameliorates oxidative status of the muscle, kidney, and heart in rats fed a highfructose diet. Nutrition Research 31: 488-495.

9. SESTERHENN K, DİSTL M, WİNK M 2007 Occurrence of iridoid glycosides in in vitro cultures and intact plants of Scrophularia nodosa L.. Plant Cell Rep 26: 365- 371.

10. BERTSOUKLİS K, PAPAFOTİOU M, BALOTİS G 2003 Effect of medium on in vitro growth and ex vitro establishment of Globularia alypum L.. ISHS Acta Horticulturae 616: I International Symposium on Acclimatization and Establishment of Micropropagated Plants.

11. GNANAPRAGASAM S, VASİL IK 1992 Ultrastructural changes in suspension culture cells of Panicum maximum during cryopreservation. Plant Cell Reports 11: 169-174.

12. JASİK J, SALAJOVA T, SALAJ J 1995 Developmental anatomy and ultrastructure of early somatic embryos in European black pine (Pinus nigra Arn.). Protoplasma 185: 205- 211.

13. WANG HL, KANG YQ, ZHANG CJ, MA Y, WANG TK 1998 Changes in nuclear ultrastructure during callus development in tissue culture of Alliumsativum. Biologia Plantarum 41(1): 49-55.

14. RİBEİRO LO, PAİVA LV, PÁDUA MS, SANTOS BR, ALVES E, STEIN VC 2012 Morphological and ultrastructural analysis of various types of banana callus, cv. Prataanã. Acta Scientiarum Doi:10.4025/actasciagron.v34i4.14501.

https://doi.org/10.4025/actasciagron.v34i4.14501

15. PADUA MS, PAİVA LV, LABORY CRG, ALVES E, STEIN VC 2013 Induction and characterization of oilpalm (Elaeis guineensis Jacq.) pro-embryogenic masses. Anais da Academia Brasileira de Ciências 85(4): 1545-1556.

16. MURASHİGE T, SKOOG F 1962 A revised medium for rapid growth and bioassay with tobacco tissue cultures. Physiol. Plantarum 15: 473-497.

17. SNEDECOR GW, COCHRAN WG 1967 Statistical methods. Iowa, USA: The Iowa State University Press. 327-329.

18. ERCETIN T, TOKER G, KARTAL M, COLGECEN H, TOKER M 2012 In vitro isoflavonoid production and analysis in 
natural tetraploid Trifolium pratense (red clover) calluses. Rev. bras. farmacogn. 22: 5 .

19. DUNCAN. D.B. 1955 Multiple range and multiple F-test. Biometrics. 11: 1-42.

20. BABAOĞLU M, GÜREL E, ÖZCAN S 2001 Bitki Biyoteknolojisi I. Doku Kültürü ve Uygulamaları. Selçuk Üniversitesi Basımevi 374.

21. MARTY F 1999 Plant Vacuoles. The Plant Cell. 11: 587-599.

22. URBANEK A, ZECHMANN B, MULLER M 2004 Plant regeneration via somatic embryogenesis in Styrian pumpkin: cytological and biochemical investigations. Plant Cell, Tissue and Organ Culture 79: 329-340.

23. LAUKKANEN H, RAUTIAINEN L, TAULAVUORI R, HOHTOLA A 2000 Changes in cellular structures and enzymatic activities during browning of Scots pine callus derived from mature buds. Tree Physiology. 20: 467-475.

24. TANG W, NEWTON RJ, OUTHAVONG V 2004 Exogenously added polyamines recover browning tissues into normal callus cultures and improve plant regeneration in pine. Physiologia Plantarum. 122: 386-395.
25. WOOLHOUSE HW 1984 Senescence in plant cells. In: Cell ageing and death, (Eds.Davies I. and Sigee D.C.), Cambridge University press, Cambridge 123-154.

26. LINNGUA G, D'AGOSTINO G, FUSCONİ A, BERTA G 2001 Nuclear changes in pathogen-infected tomato roots. Eur. J. Histochem. 45: 21-30.

27. DOORN WG, BEERS EP, DANGL JL, FRANKLIN-TONG VE, GALLOIS P, HARA-NISHIMURA I, JONES AM, KAWAIYAMADA M, LAM E, MUNDY J, MUR LAJ, PETERSEN M, SMERTENKO A, TALIANSKY M, VAN BREUSEGEM $\mathrm{F}$, WOLPERT T, WOLTERINGG E, ZHIVOTOVSKY B, BOZHKOV PV 2011 Morphological classification of plant cell deaths. Cell Death and Differentiation. 18: 1241-1246.

28. STEIN VC, PAIVA R, VARGAS DP, SOARES FP, ALVES E, NOGUEIRA GF 2010 Ultrastructural calli analysis of Inga vera Willd. subsp. Affinis (DC.) T.D. Penn. Rev. Árvore. 34:5.

29. KAEWUBON P, TOWATANA NH, SILVA J, MEESAWAT U 2015 Ultrastructural and biochemical alterations during browning of pigeon orchid (Dendrobium crumenatum Swartz) callus. Plant Cell Tiss Organ Cult. 121: 53-69. 